https:/ / doi.org/10.15407/mineraljournal.42.03.017

UDC 549.621 .98 (477)

O.A. Vyshnevskyi, PhD (Geology \& Mineralogy),

Senior Research Fellow, Leading Researcher

M.P. Semenenko Institute of Geochemistry,

Mineralogy and Ore Formation of the NAS of Ukraine

34, Acad. Palladin Ave., Kyiv, Ukraine, 03142

E-mail: vyshnevskyy@i.ua

Researcher ID: I-9996-2018

http:/ / orcid.org/0000-0002-7206-2185

\title{
COMPOSITIONAL ZONING IN PYROPE FROM SEDIMENTARY DEPOSITS OF BUG AREA (UKRAINE): IMPLICATIONS FOR UNDERSTANDING THEIR PROVENANCE
}

According to earlier concepts detrital pyrope crystals from Paleogene, Neogene and Quaternary sediments of the Upper and Middle Bug area are of kimberlitic origin. In this paper we present another hypothesis on their provenance. A purposeful microprobe examination of more than 1000 grains showed that in each sediment sample 1 to $2 \%$ of pyrope crystals are chemically inhomogeneous. With the exception of this feature, the discovered zoned garnets are completely identical in chemical composition as well as morphologically to the bulk of the detrital pyropes of the mentioned area, which indicates their single primary sources. In these crystals of 200-300 $\mu \mathrm{m}$ in size the Fe and partly Mn contents gradually increase and Mg decreases from one edge to the other, while contents of other components ( $\mathrm{Ti}$, Ca and $\mathrm{Cr}$ ) do not change, or change very slightly. The ( $\mathrm{Fe}+\mathrm{Mn})-\mathrm{Mg}$ zoning is strongest in a narrow area of 40-100 $\mu \mathrm{m}$ width near the grain rim. Maximum and minimum values of $\mathrm{Mg}$ and Fe content and their ranges in each garnet crystal are individual and differ from each other, but their average gradients of about 0.01 apfu per $10 \mu \mathrm{m}$ are approximately the same. The total range for $\mathrm{Mg}$ in analyzed garnets is $1.38-2.34$ apfu (normalized to 12 oxygen), which corresponds to 46-75 mol.\% of pyrope component; for Fe it is $0.45-1.09$ apfu and 14 to $37 \mathrm{~mol}$.\% of almandine component. The character of chemical patterns (continuous smooth concentration profiles for $\mathrm{Mg}$ and Fe, together with an almost uniform distribution of $\mathrm{Ti}, \mathrm{Cr}, \mathrm{Ca}$ ) indicates that most likely in the studied garnets there is a primary retrograde diffusion-induced zoning. Application of classical thermobarometry suggests that diffusion started to occur at temperature of about $850{ }^{\circ} \mathrm{C}$ and froze at $650{ }^{\circ} \mathrm{C}$, while pressure remained almost unchanged near $2.0 \mathrm{GPa}$. An estimation of cooling rates required to fit zoning profiles in studied garnets yields values of about 2 to $10{ }^{\circ} \mathrm{C} / \mathrm{Ma}$. In summary, in terms of the chemical composition and character of zoning the detrital pyropes of the Upper and Middle Bug area are most comparable to pyropes of orogenic peridotites. Given this, peridotites or similar rocks are suggested as the most probable primary sources of detrital pyropes within this region. However, the question on their location, proximal-regional or far distal, has no clear answer.

Keywords: pyrope, compositional zoning, diffusion, cooling rates, provenance, Upper and Middle Bug area.

Introduction. Pyrope is next to zircon the most studied detrital mineral from sedimentary deposits of different age in Ukraine. The results of its investigations are presented in dozens of articles and summarized in several monographs [e.g., 5]. Such attention to the mineral is not accidental. Since its first discovery in Ukraine in 1955, for a long time it was believed that it originates, as in Yakutia and South Africa, from kimberlites, the dominant source of diamonds worldwide. For this reason, it was used in prospecting for these rocks. As a result, from 1977 till 1998 seven non-diamondiferous kimberlite bodies were discovered within the PeriAzovian domain of the Ukrainian shield. On the contrary despite long-term exploration on the territory of the Right-Bank Ukraine (Volyn, Podolian

Cite: Vyshnevskyi O.A. Compositional Zoning in Pyrope From Sedimentary Deposits of Bug Area (Ukraine): Implications for Understanding their Provenance. Mineral. Journ. (Ukraine). 2020. Vol. 42, No. 3. P. 17-26. https://doi.org/ 10.15407/mineraljournal.42.03.017 


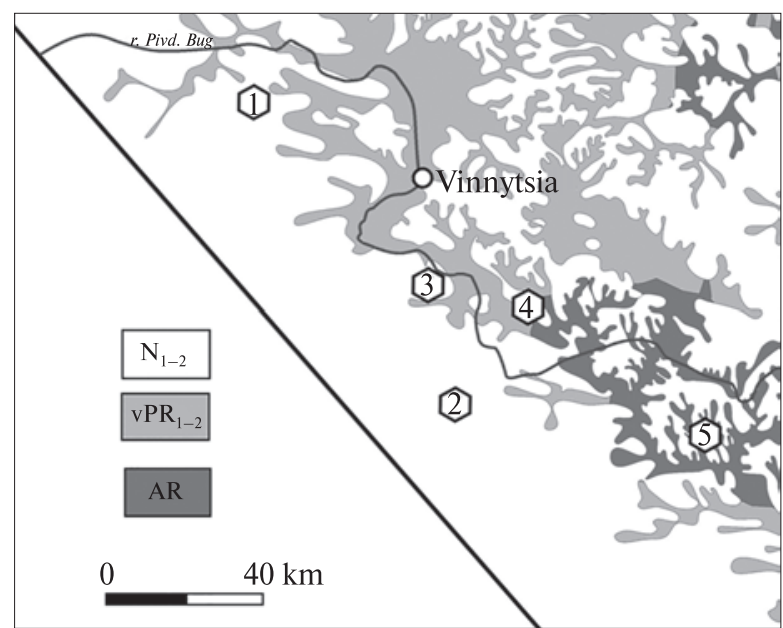

Fig. 1. Schematic geological map of Upper and Middle Bug area (modified from [6]) with points of sampling ( 1 - Kozhukhiv, 2-Shpykiv, 3 - Tyvriv, 4 - Mukhivtsi, 5 - Kleban)

and Ros-Tikich domains) the primary sources of detrital pyropes have not yet been found. Moreover, the type of their parental rocks is still not clearly identified. Also, reasonable assumptions about their possible non-kimberlitic genesis have recently appeared [2]. Thus, the question of their provenance within these territories remains open.

Despite the fact that the detrital pyropes from Right-Bank Ukraine were intensely studied, one more, previously unknown feature was recently discovered. Some of them are found to be chemi- cally inhomogeneous with varying content of $\mathrm{Mg}$, $\mathrm{Fe}$ and $\mathrm{Mn}$. In such samples Fe and partly Mn regularly increases, while $\mathrm{Mg}$ decreases across the grain. However, other components ( $\mathrm{Ti}, \mathrm{Ca}$, and $\mathrm{Cr}$ ) show no significant change.

The first detrital zoned pyropes within RightBank Ukraine were discovered in the Paleoproterozoic and Quaternary sediments on the Volyn domain of the Ukrainian Shield [3, 4], and a short time ago similar zoned grains we found among pyropes from Neogene and Quaternary sediments of Podolian domain of the Ukrainian shield. This paper presents the results of their detail microprobe investigation.

Samples and analytical techniques. Samples for this study were collected from Neogene (Sarmatian stage; Balta formation) and Quaternary fine- to coarse-grained quartz sands of Upper and Middle Bug area. Characteristics of these deposits are given in [5]. Sampling points are shown in Figure 1.

Pyropes were handpicked from heavy-mineral concentrates obtained by processing of approx. $30-35 \mathrm{~kg}$ samples of sand using standard mineral separation techniques (Wilfley table, heavy liquids and magnetic separation). About a half of extracted pyropes were mounted in epoxy-filled grain mount blocks and then polished to obtain even surfaces suitable for EMP analysis. Crystals selected for SEM study were glued to a specimen holder by means of special carbon conductive tape.
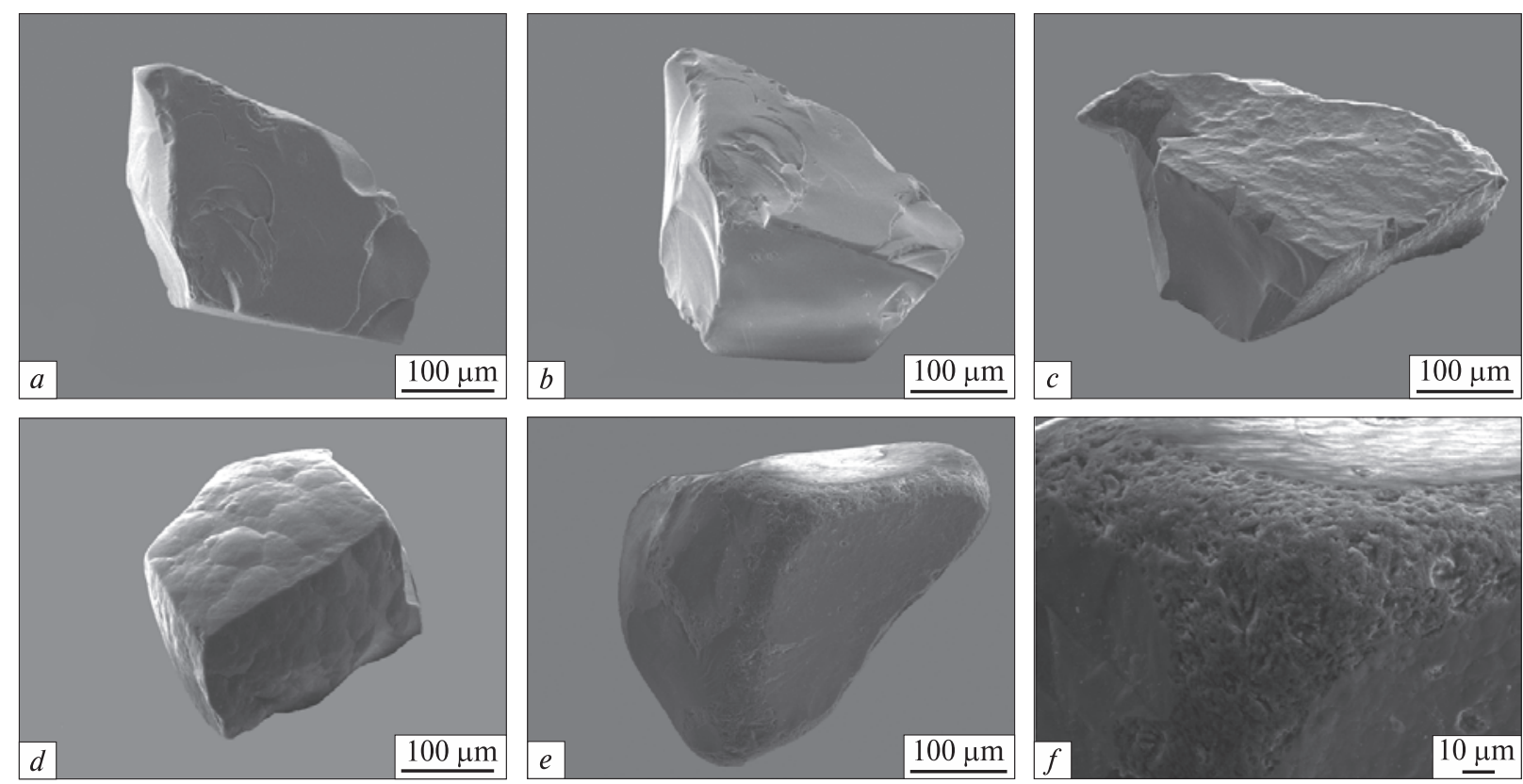

Fig. 2. Morphology of pyropes from sedimentary deposits of the Upper and Middle Bug area: $a-d-$ general view of grains, $e-f-$ pyrope with signs of mechanical abrasion, general view and detail 
SEM images and quantitative EMPA were obtained on carbon-coated samples using a field emission scanning electron microscope JSM-6700F equipped with an energy-dispersive spectrometer JED-2300 (JEOL) at the M.P. Semenenko Institute of Geochemistry, Mineralogy and Ore Formation, National Academy of Science of Ukraine. Operating conditions were as follows: $20 \mathrm{kV}$ accelerating voltage, $0.75 \mathrm{nA}$ beam current, $1 \mu \mathrm{m}$ beam size and a counting time of 60 seconds for one analysis. Pure $\mathrm{Si}, \mathrm{Ti}, \mathrm{Al}, \mathrm{Cr}, \mathrm{Fe}, \mathrm{Mn}$ and synthetic $\mathrm{MgO}, \mathrm{CaF}_{2}$ were used for calibration. Raw counts were corrected for matrix effects with the ZAF algorithm implemented by JEOL. Formulae were calculated on the basis of 12 oxygen.
Results. Within the Upper and Middle Bug area pyropes are known in Paleogene, Neogene and Quaternary sedimentary rocks, as well as in modern river alluvium, where they form dispersion halos and individual anomalies with contents from tens to thousand and more grains per $0.002 \mathrm{~m}^{3}$ of sample volume. The majority of pyrope crystals $(\sim 70-80 \%)$ has a size of $0.3-0.6 \mathrm{~mm}$, some grains reach $0.8-1.0 \mathrm{~mm}$ in diameter. These are mainly variously shaped fragments of larger grains with a smooth, shiny or sculptured surface, rarely do they have an isometric form (Fig. 2, $a-d$ ). In general, pyropes are characterized by an insignificant degree of mechanical wear, only about $15-20 \%$ of the grains have signs of slight to medium mechani-

Microprobe analyses of zoned pyropes from Neogene and Quaternary sedimentary deposits of the Upper and Middle Bug area (Ukraine)

\begin{tabular}{|c|c|c|c|c|c|c|c|c|c|c|c|c|c|c|c|}
\hline $\begin{array}{c}\text { Sample } \\
\text { No. }\end{array}$ & $\begin{array}{c}\text { Analysis } \\
\text { No. }\end{array}$ & $\mathrm{SiO}_{2}$ & $\mathrm{TiO}_{2}$ & $\mathrm{Al}_{2} \mathrm{O}_{3}$ & $\mathrm{Cr}_{2} \mathrm{O}_{3}$ & $\mathrm{FeO} *$ & $\mathrm{MnO}$ & $\mathrm{MgO}$ & $\mathrm{CaO}$ & $\operatorname{Prp}$ & Alm & Sps & Grs & $A d r$ & $U v$ \\
\hline \multirow[t]{7}{*}{ VP-71 } & 1 & 41.88 & 0.12 & 22.39 & 1.55 & 8.97 & 0.30 & 20.04 & 4.74 & 71.2 & 16.1 & 0.6 & 4.8 & 2.9 & 4.4 \\
\hline & 2 & 41.40 & 0.18 & 22.61 & 1.85 & 9.00 & 0.37 & 19.85 & 4.74 & 71.2 & 15.8 & 0.7 & 2.9 & 4.0 & 5.3 \\
\hline & 3 & 41.37 & 0.17 & 22.46 & 1.81 & 9.21 & 0.41 & 19.60 & 4.97 & 70.4 & 15.9 & 0.8 & 3.3 & 4.4 & 5.2 \\
\hline & 4 & 41.56 & 0.12 & 21.96 & 1.48 & 9.89 & 0.56 & 19.56 & 4.87 & 70.0 & 16.3 & 1.1 & 2.7 & 5.6 & 4.2 \\
\hline & 5 & 41.88 & 0.32 & 21.94 & 1.41 & 10.01 & 0.22 & 19.48 & 4.74 & 68.9 & 18.6 & 0.4 & 5.3 & 2.8 & 4.0 \\
\hline & 6 & 41.27 & 0.24 & 22.21 & 1.66 & 11.24 & 0.56 & 18.44 & 4.38 & 66.3 & 21.2 & 1.1 & 3.8 & 2.8 & 4.7 \\
\hline & 7 & 41.61 & 0.17 & 21.35 & 1.55 & 12.18 & 1.12 & 17.40 & 4.62 & 62.1 & 23.7 & 2.3 & 6.0 & 1.5 & 4.4 \\
\hline \multirow[t]{7}{*}{ VP-73 } & 1 & 41.97 & 0.21 & 23.82 & 0.87 & 7.63 & 0.36 & 21.28 & 3.88 & 75.3 & 14.1 & 0.7 & 5.4 & 2.1 & 2.4 \\
\hline & 2 & 42.09 & 0.21 & 23.82 & 0.89 & 7.71 & 0.31 & 21.01 & 3.96 & 74.1 & 15.2 & 0.6 & 6.9 & 0.6 & 2.5 \\
\hline & 3 & 42.27 & 0.07 & 24.17 & 0.70 & 8.02 & 0.25 & 20.80 & 3.72 & 74.0 & 16.0 & 0.5 & 7.3 & 0.2 & 2.0 \\
\hline & 4 & 42.00 & 0.05 & 23.72 & 0.92 & 8.64 & 0.24 & 20.69 & 3.74 & 73.4 & 16.6 & 0.5 & 6.0 & 1.0 & 2.6 \\
\hline & 5 & 41.68 & 0.18 & 23 & 0.84 & 9.69 & 0.27 & 20.07 & 3.77 & 71.5 & 18.3 & 0.5 & 5.1 & 2.2 & 2.4 \\
\hline & 6 & 41.87 & 0.18 & 23.70 & 0.63 & 10.61 & 0.28 & 19.02 & 3.71 & 68.4 & 21.4 & 0.6 & 7.3 & 0.5 & 1.8 \\
\hline & 7 & 41.57 & 0.10 & 23.56 & 0.65 & 11.57 & 0.61 & 18.53 & 3.41 & 66.6 & 23.3 & 1.2 & 6.7 & 0.3 & 1.9 \\
\hline \multirow[t]{8}{*}{ VP-76 } & 1 & 41.67 & 0.01 & 21.87 & 2.44 & 10.94 & 0.16 & 17.50 & 5.41 & 63.4 & 22.2 & 0.3 & 7.0 & 0.0 & 7.0 \\
\hline & 2 & 41.06 & 0.09 & 21.97 & 2.85 & 11.07 & 0.44 & 17.34 & 5.18 & 63.0 & 22.6 & 0.9 & 5.0 & 0.2 & 8.2 \\
\hline & 3 & 41.29 & 0.01 & 21.90 & 2.31 & 11.48 & 0.31 & 17.18 & 5.51 & 62.0 & 23.1 & 0.6 & 7.4 & 0.3 & 6.6 \\
\hline & 4 & 41.26 & 0.03 & 21.92 & 2.47 & 12.18 & 0.34 & 16.49 & 5.31 & 60.3 & 25.0 & 0.7 & 6.7 & 0.1 & 7.2 \\
\hline & 5 & 41.29 & 0.10 & 21.66 & 2.32 & 13.38 & 0.33 & 15.60 & 5.32 & 57.5 & 27.7 & 0.7 & 7.0 & 0.3 & 6.8 \\
\hline & 6 & 40.49 & 0.06 & 21.86 & 2.42 & 14.55 & 0.54 & 14.80 & 5.28 & 54.7 & 30.2 & 1.1 & 6.7 & 0.2 & 7.1 \\
\hline & 7 & 40.60 & 0.16 & 21.44 & 2.49 & 15.54 & 0.67 & 13.81 & 5.29 & 51.7 & 32.6 & 1.4 & 6.4 & 0.5 & 7.4 \\
\hline & 8 & 40.19 & 0.17 & 21.21 & 2.33 & 17.44 & 0.83 & 12.36 & 5.47 & 46.6 & 36.9 & 1.8 & 7.3 & 0.5 & 7.0 \\
\hline \multirow[t]{6}{*}{ VP-78 } & 1 & 42.34 & 0.18 & 22.19 & 1.76 & 8.39 & 0.39 & 20.36 & 4.39 & 71.6 & 16.6 & 0.8 & 5.7 & 0.5 & 4.9 \\
\hline & 2 & 42.04 & 0.18 & 22.41 & 1.72 & 8.86 & 0.43 & 19.70 & 4.66 & 69.7 & 17.6 & 0.9 & 6.5 & 0.5 & 4.9 \\
\hline & 3 & 42.08 & 0.31 & 22.57 & 1.77 & 8.98 & 0.42 & 19.43 & 4.44 & 69.6 & 18.1 & 0.9 & 5.6 & 0.8 & 5.0 \\
\hline & 4 & 41.74 & 0.13 & 22.55 & 1.69 & 9.45 & 0.38 & 19.08 & 4.97 & 68.0 & 18.5 & 0.8 & 7.1 & 0.9 & 4.8 \\
\hline & 5 & 41.86 & 0.12 & 22.52 & 1.67 & 9.51 & 0.57 & 18.97 & 4.79 & 67.6 & 19.0 & 1.2 & 7.2 & 0.3 & 4.7 \\
\hline & 6 & 41.28 & 0.15 & 22.91 & 1.88 & 10.43 & 0.44 & 18.19 & 4.72 & 65.7 & 21.1 & 0.9 & 6.4 & 0.4 & 5.4 \\
\hline
\end{tabular}

N o t e. Adr - andradite, Alm - almandine, Grs - grossular, Prp - pyrope, Sps - spessartine, Uv - uvarovite. Samples: VP-71 - Upper Bug area, Middle Sarmatian deposits, Kozhuhivskyi halo [2], VP-73 - Middle Bug area, Baltian deposits, uts. Shpykiv, VP-76 - Middle Bug area, Baltian deposits, v. Muchivtsi, VP-78 - Middle Bug area, Quaternary deposits, v. Kleban. * - total iron calculated as $\mathrm{FeO}$. 


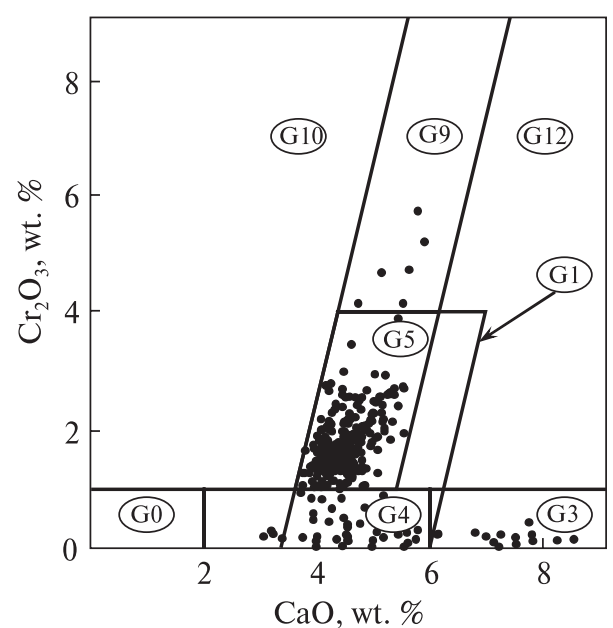

$a$

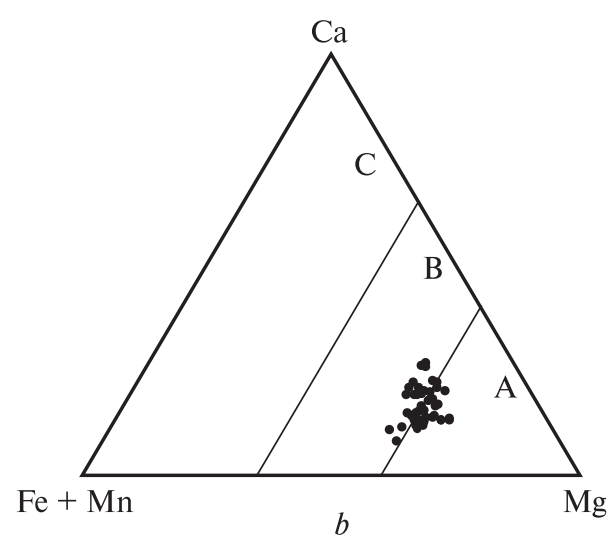

Fig. 3. Compositional diagrams for garnets from sedimentary deposits of the Upper and Middle Bug area: $a-\mathrm{Cr}_{2} \mathrm{O}_{3}$ vs. $\mathrm{CaO}$ for $\mathrm{Cr}$-pyropes; compositional fields for garnet categories (G0-G12) according to [15]; $b-$ Plot of $\mathrm{Mg}, \mathrm{Fe}$, and $\mathrm{Ca}$ (apfu) of pyrope-almandines, depicting the threefold $(\mathrm{A}, \mathrm{B}, \mathrm{C})$ classification of garnets from eclogites according to [26]

cal abrasion, such as roughness of the faces edges, presence of numerous microcaverns, among others (Fig. 2,e-f). In the Neogene Baltian deposits the occurrence of large pyropes up to $5 \mathrm{~mm}$ in size was also reported [7]. Finally, the comparative analysis shows that pyropes from sediments of different ages, as well as from different halos of the same age, have generally similar morphological features.

Chemically among the studied garnets there are two different types: Cr-saturated $\left(\mathrm{Cr}_{2} \mathrm{O}_{3}>0.5 \mathrm{wt} . \%\right)$ pyropes and $\mathrm{Cr}$-poor $\left(\mathrm{Cr}_{2} \mathrm{O}_{3}<0.5\right.$ wt.\%) almandine-pyropes. Quantitatively the first ones are significantly dominant. They form a continuous series of compositions with concentration of $\mathrm{Cr}_{2} \mathrm{O}_{3}$ from 0.5 to $5.4 \mathrm{wt} . \%$. However, the vast majority (about $80 \%$ ) contains 1.0 to 2.5 wt. $\% \mathrm{Cr}_{2} \mathrm{O}_{3}$. They have a concentration of $\mathrm{CaO}$ (3.7 to $5.1 \mathrm{wt} . \%$ ), $\mathrm{FeO}$ (6 to 10 wt.\%) and a $\mathrm{Mg}$-number $[\mathrm{Mg} /$
$(\mathrm{Mg}+\mathrm{Fe})]$ of 0.79 to 0.87 , typical for such garnets. In some samples an elevated content of $\mathrm{TiO}_{2}$ (up to $0.7 \mathrm{wt} . \%$ ) is recorded. According to Grütter's classification scheme [15] most of Cr-saturated pyropes are classified as lherzolitic (group G5) and only about $10 \%$ are pyroxenitic and websteritic (group G4) (Fig. 3, a). Cr-poor almandine-pyropes usually contain 10 to 14 wt.\% $\mathrm{FeO}$ and 4.5 to 8.5 wt. $\% \mathrm{CaO}$, and have a $\mathrm{Mg}$-number 0.65 to 0.76 . The $\mathrm{Na}_{2} \mathrm{O}$ content is basically $0.01-0.04$ wt. $\%$, in individual grains it can reach $0.07 \mathrm{wt} . \%$. Considering the chemical composition of the studied $\mathrm{Cr}-$ poor garnets, their eclogitic paragenesis is not in doubt. In the classification scheme of Taylor and Neal [26] they are of types A and B (Fig. 3, b). It is important to note that studied garnets, both pyropes and almandine-pyropes, from sediments of different ages, as well as from different halos of the same age, are identical in chemical composition.

A systematic microprobe examination of more than 1000 grains showed that in each sediment sample 1 to $2 \%$ of pyrope crystals are zoned and the character of zoning is the same as in the earlier studied zoned pyropes from Volyn area [3, 4].

A detailed study of four chemically inhomogeneous grains of pyrope from several sediment samples showed the following:

1. In all of them the Fe and partly Mn contents gradually increase, and $\mathrm{Mg}$ decreases from one edge to the other and, what is important, only in one direction. The other components ( $\mathrm{Ti}, \mathrm{Ca}$ and $\mathrm{Cr}$ ) do not change, or change very slightly (Table, Figs 4, 5);

2. The $(\mathrm{Fe}+\mathrm{Mn})-\mathrm{Mg}$ zoning is strongest in a narrow area of 40 to $100 \mu \mathrm{m}$ width near the grain rim;

3. The maximum and minimum values of $\mathrm{Mg}$ and $\mathrm{Fe}$ content and their ranges in each studied crystal are individual and differ from each other, but their average gradients are approximately the same and are about 0.01 apfu per $10 \mu \mathrm{m}$, with the exception of sample VP-76, in which these values are twice as high;

4. The total range for $\mathrm{Mg}$ is 1.38 to $2.34 \mathrm{apfu}$ which corresponds to $46-75 \mathrm{~mol} \%$ of pyrope component; for Fe the range is 0.45 to 1.09 apfu corresponding to $14-37 \mathrm{~mol} \%$ of almandine component;

5. All zoned garnets are free of inclusions, at least of a few $\mu \mathrm{m}$ and larger size, based on observation under an optical binocular microscope and in the BSE mode on SEM;

6 . With the exception of the observed $\mathrm{Fe}-\mathrm{Mg}$ inhomogeneity, by other signs of chemical composi- 

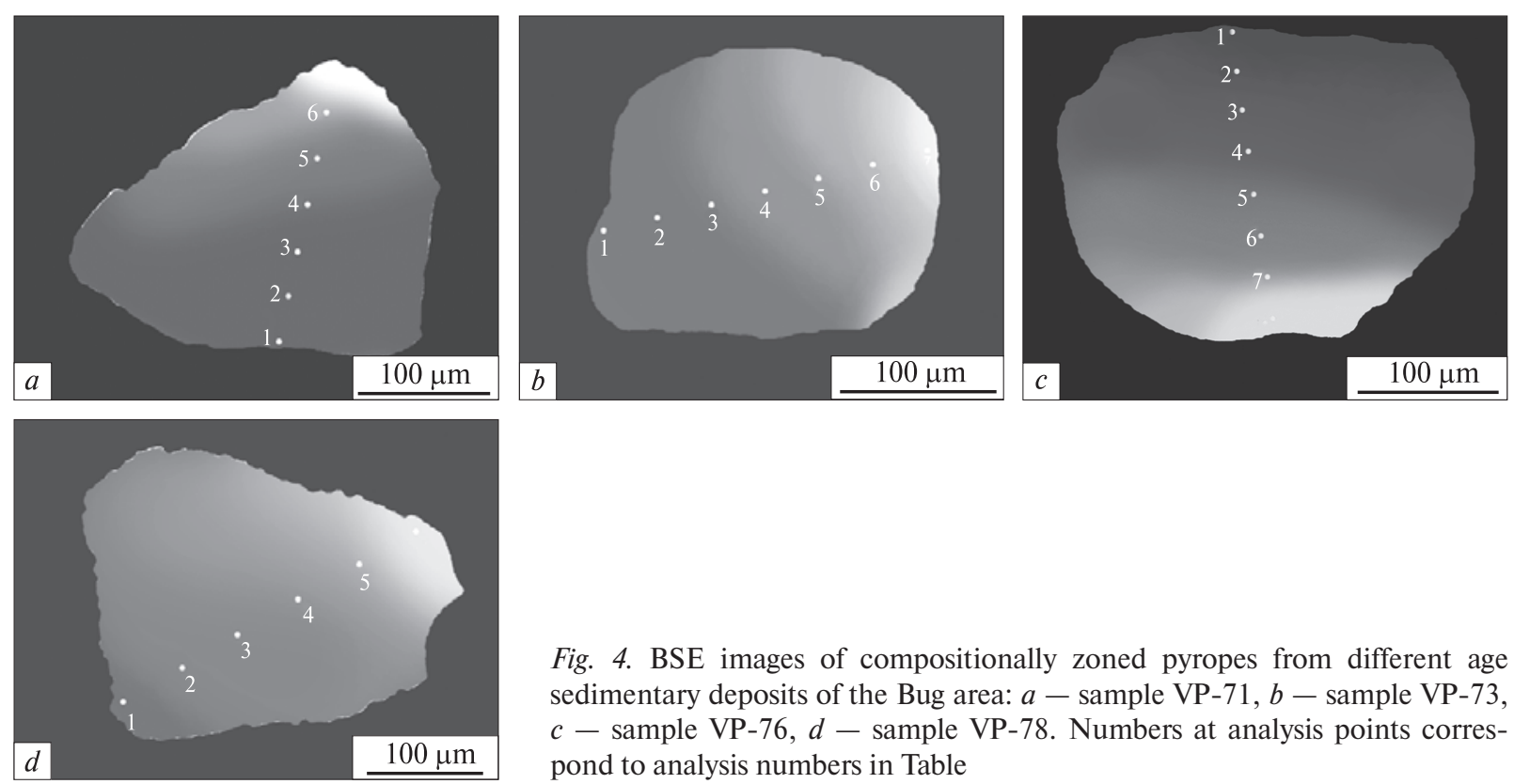

Fig. 4. BSE images of compositionally zoned pyropes from different age sedimentary deposits of the Bug area: $a$ - sample VP-71, $b$ - sample VP-73, $c$ - sample VP-76, $d$ - sample VP-78. Numbers at analysis points correspond to analysis numbers in Table

tion, as well as morphologically, the studied zoned garnets are identical to the bulk of the detrital pyropes of the Upper and Middle Bug area.

Discussion. Chemically zoned pyropes are known in ultramafic rocks of different age (from Proterozoic to Cenozoic) and tectonic settings (cratonic, off-cratonic and orogenic). To date they are described from cratonic garnet peridotites (xenoliths in kimberlites) [e.g., 8, 9, 11, 18, 19, 24] and kimberlite groundmass [e.g., 10], off-cratonic volcanic rocks (e.g., serpentinized ultramafic microbreccia of the Colorado Plateau [e.g., 17, 31]), and from orogenic garnet peridotites from the Proterozoic (the Western Gneiss Region, SW Norway [25 and references therein]), the Paleozoic (Bohemian Massif, Czech Republic [20, 21 and references therein]), the Mesozoic (Pohorje NE Slovenia [e.g., 29], and the Cenozoic (Central Alps, Switzerland [e.g., 13, 22 and references therein]). Literature data reveal a large variety of zoning patterns in garnet that correspond with tectonic settings of their host rocks. So, in cratonic rocks the chemical inhomogeneity of pyropes is quite rare, but if present usually diverse and complicated, while in off-cratonic and orogenic areas it is common and typically relatively simple.

Most of zoning patterns in garnets from deepseated xenoliths in kimberlites and kimberlite groundmass show a significant difference between core and rim composition: the transition from core to rim can be sharp, step-like or oscillatory in some samples and smooth in others. Compositional variation in such heterogeneous garnets involves the basic elements $\mathrm{Cr}, \mathrm{Ca}, \mathrm{Ti}, \mathrm{Mg}, \mathrm{Fe}$, and $\mathrm{Al}$, and a number of zoning patterns are distinguished. The commonest are: i) significant core to rim decrease in $\mathrm{Cr}$ and $\mathrm{Ca}$, compensated by $\mathrm{Ti}, \mathrm{Mg}, \mathrm{Al}$ and $\mathrm{Fe}$; ii) sharp core to rim increasing in $\mathrm{Ca}$ and decreasing in $\mathrm{Mg}$ accompanied by a slight decrease in $\mathrm{Cr}$ at a near constant $\mathrm{Fe}$. Such complicated zoning, as suggested in $[8,11,12,19,24]$, could be formed either during garnet growth, due to changes in temperature and/or pressure, or formed after growth during metasomatism. It should be also noted that genuine growth zoning in garnets in deep-seated xenoliths is relatively rare, because chemical inhomogeneity is erased or weakened by diffusion during the long residence time in the mantle at high temperature [18].

In contrast, in off-cratonic and orogenic rocks compositional zoning in garnets is more common and usually rather simple. For example, in off-cratonic ultramafic diatremes of the Colorado Plateau pyropes have pronounced concentric 50 to $60 \mu \mathrm{m}$ wide $\mathrm{Fe}-\mathrm{Mg}$ zoning around olivine inclusions [17]. In orogenic peridotites $(\mathrm{OP})$, garnets generally have relatively homogeneous cores and compositional zoning, if present, is usually confined to a narrow area of 100 to $200 \mu \mathrm{m}$ at grains rims. E.g. in the Czech peridotites, pyropes have compositionally uniform cores, but show an increase in Fe and concomitant decrease in $\mathrm{Mg}$ at contacts to olivine and pyroxene. It is believed that such zoning is due to diffusion and caused by arrested $\mathrm{Fe}-\mathrm{Mg}$ exchange between garnet and adjacent ferromagnesian silicates during cooling [20]. It is 


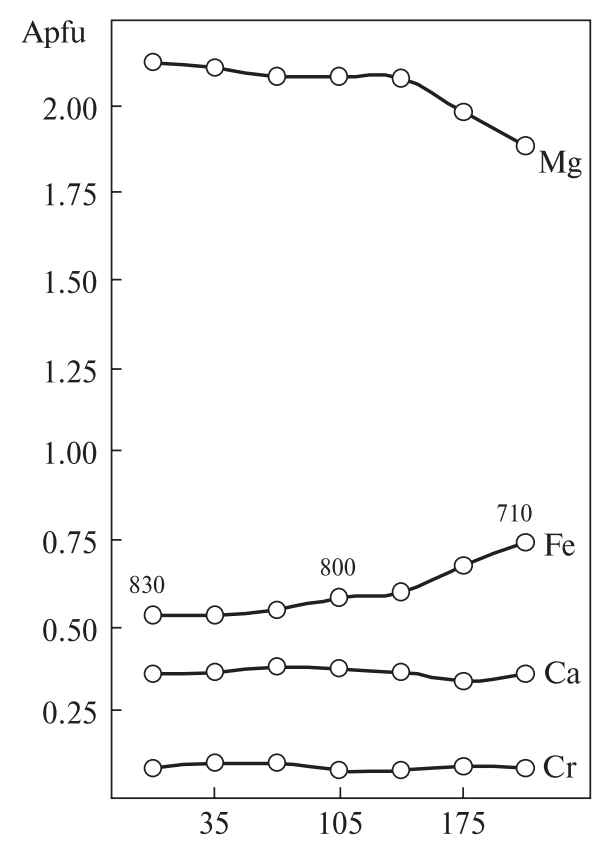

$a$

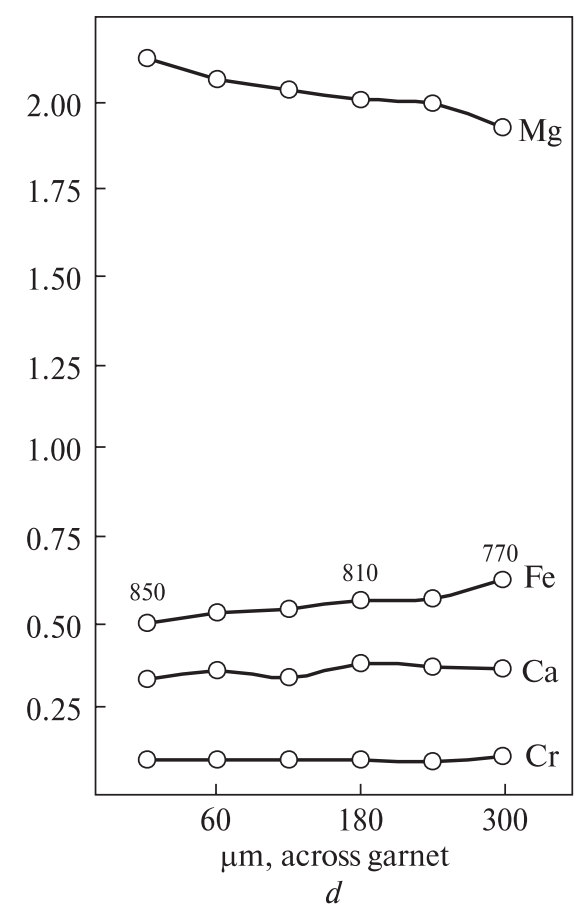

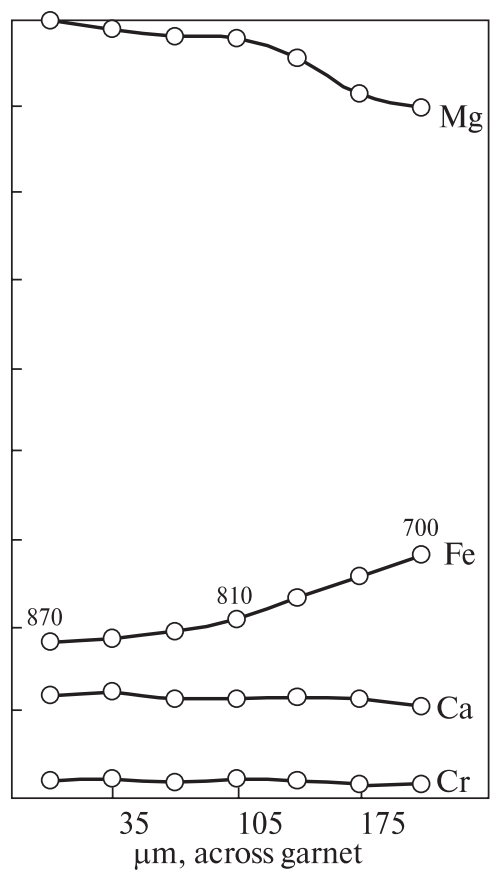

$b$

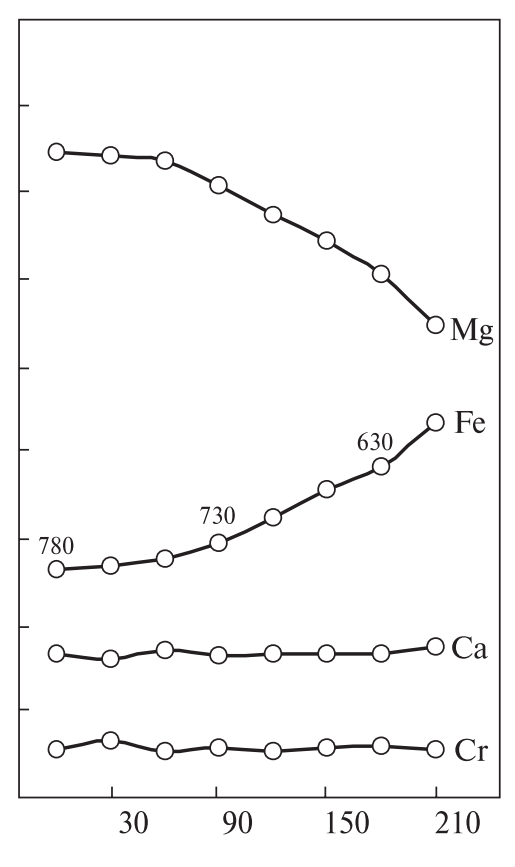

$c$

Fig. 5. Microprobe traverses across compositionally zoned pyropes from Neogene and Quaternary sedimentary deposits of the Upper and Middle Bug area. Open circles are analytical points. Numbers at analytical points correspond to temperature $\left({ }^{\circ} \mathrm{C}\right)$ estimated by garnet-olivine geothermometer (see text): $a-$ sample VP-71, $b-\mathrm{VP}-73, c-\mathrm{VP}-76, d-$ VP-78

important to note that this phenomenon is significant in garnets, but negligible or absent in adjacent olivines and pyroxenes. This likely reflects a higher diffusivity of $\mathrm{Mg}$ and $\mathrm{Fe}$ in the latter than in pyropes. A contrasting zoning with increasing $\mathrm{Mg}$ and decreasing Fe from core to rim was documented in garnets in some peridotite bodies of the Seve Nappe complex (Jamtland, Sweden), interpreted as growth zoning during prograde metamorphism [27]. Rarely pyropes in orogenic peridotites have a more complex compositional zoning, e.g. in peri-

dotites of the Otroy island (Western Gneiss Region, Norway), which reveal significant increase in Fe and $\mathrm{Mn}$ from core to rim, accompanied by decrease in $\mathrm{Cr}$ and $\mathrm{Ca}$, at relatively constant $\mathrm{Mg}$ [28]. Another, unusual type of compositional heterogeneity was recorded in pyropes from peridotites of the Pohorje Mountains (Eastern Alps, Slovenia) [29]. In these garnets an irregular patchy distribution of $\mathrm{Mg}, \mathrm{Fe}$ and $\mathrm{Ca}$ is observed. Some areas within the crystals are enriched in $\mathrm{Mg}$ but depleted in $\mathrm{Fe}$ and $\mathrm{Ca}$, while in others it is vice versa. It is suggested 
that during decompression $\mathrm{Mg}$ is moving out of garnet which results in enrichment of $\mathrm{Ca}$ and $\mathrm{Fe}$, and relatively slow diffusion processes caused an irregular distribution of components that resulted in the patchy texture.

The character of zoning of pyrope crystals from sedimentary deposits of Upper and Middle Bug area and their major elements composition are most similar to those of the orogenic garnet peridotites. Therefore, for our further considerations we will proceed from the hypothesis that they originate from such or similar types of rocks.

As mentioned above, detrital pyropes of Bug area, including zoned ones which is 1 to $2 \%$ of the total amount, mainly have a size of 0.3 to $0.6 \mathrm{~mm}$ and are fragments of larger crystals. Given these facts, the estimated dimension of the initial crystals in the bedrocks could be 5 to $6 \mathrm{~mm}$ or more, which is typical for garnets in orogenic peridotites. Such large pyrope porphyroclasts in the latter are often heavily fractured. Therefore, during erosion of the host rock, transport and deposition in the sediments they easily disintegrate and produce mmsized fragments, which are dispersed and can form halos directly near to the primary source. On the other hand, it is known [e.g., 1] that under certain conditions fine-grained crystals (less than $1 \mathrm{~mm}$ ) can be transported practically without abrasion over distances of more than $100 \mathrm{~km}$. Thus, considering the morphological features of detrital pyropes of the Upper and Middle Bug area, one can suppose both proximal and far distal (up to several hundred kilometers from points of their current deposition) primary source rocks. To comprehend the situation more deeply, a more detailed morphological analysis of these garnets and other accompanying heavy minerals, together with data on geology and geological history of Bug and neighboring areas, would be required.

The second important question for discussion is the nature of and reasons for zoning discovered in pyropes of the Bug area. However, the interpretation of the observed inhomogeneity is quite complicated, because we have only fragments of crystals. Thus, it is not known which part of the crystals (inner, intermediate or external) we are dealing with and in what direction (from core to rim or vice versa) $\mathrm{Mg}$ increased and Fe decreased. For this reason, we restrict ourselves only to general considerations.

The observable chemical patterns (not oscillatory or step-like, but continuous smooth concentration profiles for $\mathrm{Mg}$ and $\mathrm{Fe}$, together with an almost uniform distribution of $\mathrm{Ti}, \mathrm{Cr}, \mathrm{Ca}$ within the crystals) allows suggesting that most likely in the studied garnets we have a primary diffusion-induced zoning. Also, initially it might have been growth zoning (it remains uncertain if prograde or retrograde) which later was relaxed by diffusion.

Pyropes with major elements diffusion zoning are currently recorded in all of the above-mentioned rocks, but the length of diffusion profiles in garnets is different. The shortest ones, not more than a few tens of $\mu \mathrm{m}$, are typical for garnets from cratonic rocks (kimberlites and their mantle xenoliths), a little bit wider is documented in off-cratonic volcanics, and the longest ones, up to several hundreds of $\mu \mathrm{m}$ are characteristic for garnets in orogenic peridotites. In the fragments of detrital zoned pyropes from the Bug area, the diffusion profiles are between 150 to $220 \mu \mathrm{m}$, and most likely they were even longer, but were shortened due to physical and chemical weathering during sedimentation history. Thus, the examined pyropes are most similar to those of orogenic peridotites, which is one more weighty argument to consider orogenic peridotites or similar rocks as their most probable primary source.

Compositional zoning in pyrope garnets is of special interest to infer the PTX-conditions of host-rocks during and after their crystallization, and to obtain timescales of various processes such as cooling and exhumation rates. Given this, we also carried out and present here such estimates, clearly understanding that they are simplified and not complete, but they are very helpful for the question of the provenance of detrital pyropes of the Bug area.

PT-estimates were performed according to the algorithm proposed in [30]. Pressure was calculated using the Cr-in-pyrope barometer developed by Grütter, Latti \& Menzies [16]. To determine the temperature a two-step scheme was applied. Firstly utilizing the equation:

$$
\mathrm{X}_{\mathrm{Fe}}^{\mathrm{Ol}}=0.0184+0.3895 \mathrm{X}_{\mathrm{Fe}}^{\mathrm{Grt}}
$$

that describes a significant positive correlation $\left(r^{2}=0.91\right)$ between the Fe-numbers (molar Fe/ $(\mathrm{Fe}+\mathrm{Mg}))$ of coexisting pyropes and olivines (based on more than 250 pairs), for each measured pyrope composition the olivine composition, with which it should be in equilibrium is calculated; secondly at a given pressure, the equilibrium temperature is determined using a garnet-olivine thermometer. In our study we choose the O'Neill \& Wood calibration [23], most often used to calculate 
garnet-olivine equilibrium temperatures for highpressure paragenesis.

For all studied samples the Cr-in-pyrope barometer yielded a pressure range in different samples from 1.7 to $2.2 \mathrm{GPa}$. The values calculated for different points within each individual sample are almost the same. In contrast, the temperature estimates in individual grains at points along the traverses differ significantly (Fig. 5). The largest difference between extreme points in one sample is about $200{ }^{\circ} \mathrm{C}$, mostly it is within 70 to $120^{\circ} \mathrm{C}$. The whole temperature range for all samples is 870 to $630{ }^{\circ} \mathrm{C}$. Summarizing the above estimates and assuming a retrograde zoning, which is typical for garnets in most orogenic peridotites, we can conclude that diffusion processes started at about $850^{\circ} \mathrm{C}$ and froze at $650^{\circ} \mathrm{C}$. The process was almost isobaric at approximately $2.0 \mathrm{GPa}$.

The existence of wide retrograde diffusion profiles in the studied pyropes is direct evidence for slow cooling of their parent rocks, after final crystallization of their primary mineral assemblages. By our preliminary rough estimates, utilizing the diffusion equation and $\mathrm{Fe}-\mathrm{Mg}$ interdiffusion coefficients (the self-diffusion coefficients were computed from the data of [14]), the time required for their producing at 850 to $650{ }^{\circ} \mathrm{C}$ and $2.0 \mathrm{GPa}$ is between 10 and $90 \mathrm{Ma}$. Based on this and the observed length of the profiles, the calculated cooling rates of the host rocks are about 2 to $10{ }^{\circ} \mathrm{C} / \mathrm{Ma}$. These values are in good agreement with those obtained earlier for peridotites in Czechia [20]. Once again, we emphasize that these are only preliminary estimates. A detailed research on this question, including a fine-step microprobe scanning of the compositionally zoned pyropes of the Bug area, accompanied by numerical modeling of their diffusion profiles and more accurate calculation of cooling rates is in progress.

Conclusions. Summarizing the above it can be concluded:

1. About 1 to $2 \%$ of detrital pyropes, which are otherwise identical in chemical composition and morphology to the bulk of the detrital pyropes from sedimentary deposits of the Upper and Middle Bug area, reveal $\mathrm{Fe}-\mathrm{Mg}$ diffusion zoning. This indicates their single primary source.

2. In terms of chemical composition and character of zoning, the detrital pyropes of the Upper and Middle Bug area are most comparable to pyropes of orogenic peridotites ("OP-type"). Given this, we consider the latter or similar types of rocks as the most probable primary source of detrital pyropes within this region.

3. The presence of "OP-type" pyropes in sedimentary deposits of the Upper and Middle Bug area is a good hint to assume the existence of pyrope peridotite bodies or their remnants (similar to those from the Western Gneiss Region, Moldanubian Zone, etc.), enclosed in UHP metamorphic rocks of the Bug granulite complex. They are most likely small in dimensions (up to several meters across) and for this reason could have been missed during geological mapping and prospecting. And if they will be discovered, this will contribute to a better understanding of the metamorphic and tectonic history of the Bug area. However, we do not exclude for them a distal primary source (up to several hundred kilometers away from their current deposition).

Thus, at this moment we have a decision on the type of parent rocks of the studied detrital pyropes, while the question of their location remains open.

\section{REFERENCES}

1. Afanasiev, V.P., Nikolenko, E.I., Tychkov, N.S., Titov, A.T., Tolstov, A.V., Kornilova, V.P. and Sobolev, N.V. (2008), Geologyia i Geofizyka, Vol. 49, No. 2, Novosibirsk, RU, pp. 120-127 [in Russian].

2. Vyshnevskyi, O.A., Pavliuk, O.V. and Pavliuk, V.M. (2012), Mineral. Journ. (Ukraine), Vol. 34, No. 1, Kyiv, UA, pp. $25-$ 34 [in Ukrainian].

3. Vyshnevskyi, O.A. (2014), Dopov. Nac. akad. nauk Ukr., No. 3, Kyiv, UA, pp. 98-103 [in Ukrainian].

4. Vyshnevskyi, O.A. (2015), Zap. Ukr. mineral. tov., Vol. 12, Kyiv, UA, pp. 130-133 [in Ukrainian].

5. Heiko, Yu.V., Hurskyi, D.S., Lykov, L.I., Metalidi, V.S., Pavliuk, V.N., Prykhodko, V.L., Tsymbal, S.N. and Shymkiv, L.M. (2006), Perspektivy korennoi almazonosnosti Ukrainy, Tsentr Europy publ., Kyiv-Lviv, UA, 223 p. [in Russian].

6. (1998), Geologicheskaya karta Ukrainy i Moldovy, 1 : 1000000.

7. Druzhynin, L.M., Hritsik, K.P., Lavrov, D.A. and Smirnov, G.I. (1976), Dopov. AN UkrRSR, Ser. B, No. 6, UA, pp. 491493 [in Ukrainian].

8. Lazko, E.E. and Serenko, V.P. (1983), Izvestiya AN SSSR, Ser. Geol., No. 12, RU, pp. 41-53 [in Russian].

9. Serenko, V.P., Nikishov, K.N. and Lazko, E.E. (1982), Dokl. AN SSSR, Vol. 267, No. 2, RU, pp. $438-441$ [in Russian].

10. Sobolev, N.V. (1974), Glubinnye vkliucheniya v kimberlitakh i problema sostava verkhnei mantii, Nauka, Novosybirsk, RU, 261 p. [in Russian]. 
11. Tychkov, N.S., Pokhilenko, N.P., Kuligin, S.S. and Malygina, E.V. (2008), Geologyia i Geofizyka, Vol. 49, No. 4, Novosibirsk, RU, pp. 302-318 [in Russian].

12. Burgess, S.R. and Harte, B. (1999), Proc. 7th Kimberlite Conf. (Dawson volume), Cape Town, pp. 66-80.

13. Das, S. and Basu, A.R. (2019), Int. Geol. Rev. https://doi.org/10.1080/00206814.2019.1703223

14. Ganguly, J., Cheng, W. and Chakraborty, S. (1998), Contribs Mineral. and Petrol., Vol. 131, pp. 171-180.

15. Grütter, H.S., Gurney, J.S., Menzies, A.H. and Winter, F. (2004), Lithos, Vol. 77, Iss. 1-4 [special issue], pp. $841-857$. https://doi.org/10.1016/j.lithos.2004.04.012

16. Grütter, H., Latti, D. and Menzies, A. (2006), J. Petrol., Vol. 47, No. 4, pp. 801-820. https://doi.org/10.1093/petrology/ egi096

17. Hunter, W.C. and Smith, D. (1981), Contribs Mineral. and Petrol., Vol. 76, pp. 312-320.

18. Jollands, M.C., Hanger, B.J., Yaxley, G.M., Hermann, J. and Kilburn, M.R. (2018), Earth. Planet. Sci. Lett., Vol. 481, pp. 143-153. https://doi.org/10.1016/j.epsl.2017.10.021

19. Kargin, A.V., Sazonova, L.V., Nosova, A.A. and Tretyachenko, V.V. (2016), Lithos, Vol. 262, pp. 442-455. https://doi. org/10.1016/j.lithos.2016.07.015

20. Medaris, G.Jr., Wang, H., Jelınek, E., Mihaljevic M., and Jakes, P. (2005), Lithos, Vol. 82, pp. 1-23. https://doi. org/10.1016/j.lithos.2004.12.004

21. Medaris, G.Jr., Ackerman, L., Jelinek, E., Toy, V., Siebel, W. and Tikoff, B. (2009), J. Geosci., Vol. 54, pp. 301-323. https://doi.org/10.3190/jgeosci.052

22. Nimis, P. and Trommsdorff, V. (2001), J. Petrol., Vol. 42, No. 1, pp. 103-115. https://doi.org/10.1093/ petrology/42.1.103

23. O’Neill, H.S.C. and Wood, B.J. (1979), Contribs Mineral. and Petrol., Vol. 70, pp. 59-70.

24. Smith, D. and Boyd, F.R. (1992), Contribs Mineral. and Petrol., Vol. 112, pp. 134-147.

25. Spengler, D., van Roermund, H.L.M. and Scheffler, F. (2019), Lithos, Vol. 350-351. https://doi.org/10.1016/j. lithos.2019.105217

26. Taylor, L.A. and Neal, C.R. (1989), J. Geol., Vol. 97, pp. 551-567.

27. van Roermund, H.L.M. (1989), The Caledonide Geology of Scandinavia, London, Graham and Trotman, pp. 205219.

28. van Roermund, H.L.M., Drury, M.R., Barnhoorn, A. and De Ronde, A. (2001), J. Petrol., Vol. 42, pp. 117-130. https:// doi.org/10.1093/petrology/42.1.117

29. Vrabec, M. (2010), Geologija, Vol. 53, No. 1, pp. 21-36. https://doi.org/10.5474/geologija.2010.002

30. Vyshnevskyi, O.A. (2019), Abstr. Sci. conf., dedicated to the $50^{\text {th }}$ Anniversary of M.P. Semenenko Inst. of Geochemistry, Mineralogy and Ore Formation NAS of Ukraine, Kyiv, May 14-16, 2019, in 2 vol. M.P. Semenenko IGMOF NAS of Ukraine, Kyiv, UA, Vol. 1, pp. 134-135.

31. Wang, L., Essene, E.J. and Zhang, Y. (1999), Contribs Mineral. and Petrol., Vol. 135. pp. 164-178.

Received 20.05.2020

O.А. Вишневський, канд. геол.-мін. наук, пров. наук. співроб.

Інститут геохімії, мінералогії та рудоутворення

ім. М.П. Семененка НАН України

03142, Київ, Україна, пр-т Акад. Палладіна, 34

E-mail: vyshnevskyy@i.ua

Researcher ID: I-9996-2018

http://orcid.org/0000-0002-7206-2185

\section{КОМПОЗИЦІЙНА ЗОНАЛЬНІСТЬ ПІРОПІВ ІЗ ОСАДОВИХ ВІДКЛАДІВ ПОБУЖЖЯ: ЗНАЧЕННЯ ДЛЯ РОЗУМІННЯ ЇХ ПОХОДЖЕННЯ}

Тривалий час вважалося, що детритові піропи, поширені у палеогенових, неогенових і четвертинних відкладах Верхнього та Середнього Побужжя, пов'язані з кімберлітами. У цій роботі ми представляємо інше бачення їхнього походження. Цілеспрямоване мікрозондове дослідження понад тисячі зерен продемонструвало, що в кожній шліховій пробі 1-2\% піропів є хімічно неоднорідними. За винятком цієї особливості, за іншими ознаками хімічного складу, так само як і за морфологічними особливостями, виявлені зональні індивіди повністю ідентичні усім іншим детритовим піропам названої області, що вказує на їхні спільні корінні джерела. Розмір таких кристалів 200-300 мікрометрів, вміст у них заліза та, частково, марганцю поступово збільшується, а магнію зменшується від одного краю до іншого, тоді як вміст інших компонентів ( Тi, Сa i Cr) не змінюється, або змінюється дуже незначно. (Fe $+\mathrm{Mn})-\mathrm{Mg}$ зонування найістотніше проявляється на відносно вузькій ділянці шириною 40-100 мікрометрів біля краю зерна. Максимальні та мінімальні значення вмісту $\mathrm{Mg}$ та Fe та їхні діапазони в будь-якому досліджуваному гранаті індивідуальні та відрізняються один від одного, але середні їхні градієнти приблизно однакові і становлять близько 0,01 ф. о. на 10 мкм. Загальний діапазон вмісту магнію у проаналізованих зональних гранатах становить 1,38-2,34 ф. о. (у перерахунку на 12 атомів кисню), що відпові- 
дає 46-75 мол. \% піропового компонента, заліза, відповідно, 0,45-1,09 ф. о. та 14-37 мол. \% альмандинового компонента. Характер хімічної зональності, а саме безперервні плавні концентраційні профілі для $\mathrm{Mg}$ і $\mathrm{Fe}, \mathrm{pazoм}$ із майже рівномірним розподілом $\mathrm{Ti}, \mathrm{Cr}$, Са у межах кристалів, свідчать про те, що, радше за все, у досліджених гранатах ми маємо первинну ретроградну дифузійну зональність. Розрахунки, виконані за методами класичної геотермобарометрії, дають змогу припускати, що процес $\mathrm{Mg}-\mathrm{Fe}$ дифузії розпочався за температури близько $850{ }^{\circ} \mathrm{C}$ і припинився за $650{ }^{\circ} \mathrm{C}$, тоді як тиск у цей час залишався майже незмінним і становив близько 2,0 ГПа. Оцінювання швидкості охолодження корінних порід, необхідної для утворення профілів зонування, що спостерігаються у досліджених гранатах, дає значення приблизно від 2 до $10{ }^{\circ} \mathrm{C} / \mathrm{Mлн} \mathrm{рр.} \mathrm{Загалом} \mathrm{за} \mathrm{особливостями} \mathrm{хімічного} \mathrm{складу}$ та характером виявленої у них зональності детритові піропи Верхнього та Середнього Побужжя найбільше подібні до піропів орогенних перидотитів. 3 урахуванням цього у статті висловлено припущення, що останні або подібні до них породи є найімовірнішими корінними джерелами детритових піропів, поширених у досліджуваному регіоні. Однак на питання, чи є вони місцевими, чи значно віддаленими, обгрунтованої відповіді поки що немає.

Ключові слова: піроп, композиційна зональність, дифузія, швидкість охолодження, походження, Верхнє та Середнє Побужжя. 